\title{
Bimbingan Teknis Digitalisasi Promosi Berbasis Website dan Media Sosial Daya Tarik Wisata Air Terjun Kedung Angin Desa Pakel Kecamatan Licin Kabupaten Banyuwangi
}

\author{
Nurhalimah*1, Randhi Nanang Darmawan², Kanom³ \\ 1,2,3 Manajemen Bisnis Pariwisata, Politeknik Negeri Banyuwangi, Indonesia \\ *e-mail: nurhalimah@poliwangi.ac.id1ㅗ.randhi@poliwangi.ac.id² ${ }^{2} \underline{\text { kanom@poliwangi.ac.id }}^{3}$
}

\begin{abstract}
Abstrak
Pandemi Covid 19 di akhir 2109 dan di awal 2020 yang melanda Indonesia juga membuat wisata air terjun Kedung Angin tutup total, hasil observasi dengan Mitra daya tarik ini dikelola langsung oleh Badan Usaha Milik Desa (BUMDes) Pakel, namun dengan pengelolaan di bidang pariwisata mulai dari tata kelola hingga strategi pemasaran yang kacau mengingat SDM nya masih minim pemahaman dan pengetahuan. Menyambut kebiasaan baru pariwisata maka tim pelaksana Pengabdian kepada Masyarakat melakukan Bimbingan Teknis (Bimtek) kepada pengelola untuk melakukan suatu strategi dan langkah nyata dalam bidang Digitalisasi Promosi berbasis website dan media sosial. Metode yang digunakan adalah bimbingan teknis berupa pelatihan dan pendampingan untuk meningkatkan kompetensi peserta khususnya dibidang promosi pariwisata yang mana konsep Bimtek dengan pendekatan Pariwisata Berbasis Masyarakat dan Ekowisata. Hasil dari kegiatan ini berdampak nyata dari sisi tata kelola Air Terjun Kedung Angin yang mulai lebih bersih dan lebih baik dari sebelumnya disamping itu pengelola melalui pemuda desa mulai sadar dengan melakukan promosi melalui media sosial dan memanfaatkan website https://kedungangin.com lebih maksimal. Harapan Tim PKM kepada pengelola agar dapat bersinergi dengan pihak-pihak terkait dalam melakukan digitaliasasi promosi sehingga dapat melestarikan lingkungan, mengedepankan kearifan lokal, dan menggerakkan UMKM di Desa Pakel dan lingkungan sekitar Air Terjun Kedung Angin.
\end{abstract}

Kata kunci: Air Terjun Kedung Angin, Bimbingan Teknis, Digitalisasi Promosi, Pariwisata Berbasis Masyarakat

\section{Abstract}

The Covid 19 pandemic at the end of 2109 and in early 2020 that hit Indonesia and also made the Kedung Angin waterfall tour completely closed, the observations result with this attraction partner were managed directly by the Pakel Village-Owned Enterprise or called BUMDes, but with the management of new habits in the tourism sector ranging from governance to marketing strategies that are chaotic considering that human resources are still lacking in understanding and knowledge. Welcoming the new tourism habit, the team of community service conducted Technical Guidance to managers to carry out a strategy and concrete steps to welcome the field of Digitalization Promotions based on websites and social media. The method used is technical guidance in the form of training and mentoring to improve the competence of participants, especially in the field of tourism promotion which is the concept with Community-Based Tourism approach and ecotourism. The results of this activity have a real impact in terms of governance of Kedung Angin Waterfall, which is starting to be cleaner and better than before. Besides that, managers through village youth are starting to realize that they are doing promotions through social media and making maximum use of the website https://kedungangin.com. The team of community services hope to managers so that they can synergize with related parties in digitalizing promotions so that they can preserve the environment, promote local wisdom, and mobilize MSMEs in Pakel Village and the environment around Kedung Angin Waterfall.

Keywords: Community-Based Tourism, Digitalization Promotion, Kedung Angin Waterfall, Technical Guidance

\section{PENDAHULUAN}

Banyuwangi adalah kabupaten terluas di Jawa Timur dengan luas wilayah 5.782,50 km². Mayoritas penduduknya adalah suku Osing. Namun, banyak juga suku lain, seperti Madura, Jawa, Bali, dan Bugis. Yang terlintas di benak orang mengenai Banyuwangi adalah santet. Apalagi pada 
1998 kota ini pernah mengalami kejadian mistis yang di luar nalar. Tragedi pembunuhan yang banyak memakan korban jiwa itu dituduh terjadi karena ilmu santet. Namun, di balik cerita mistis mengenai santet, kota ini menyimpan sejuta rahasia dengan beragam kuliner yang sangat lezat, budaya yang sangat patut dinikmati dan dipelajari, dan tempat wisata yang indah. Banyuwangi juga mempunyai julukan The Sunrise of Java (Winarta, 2017).

Kabupaten Banyuwangi semakin menarik wisatawan asing maupun lokal karena keindahan dan ciri khas yang tidak ditemui di tempat lain. Wisata di kota ini sangat beragam dan sedang hits di kalangan traveler. Tidak hanya Kawah Ijen, Pantai Boom, Watu Dodol, Teluk Hijau, Rawa Banyu, Air Terjun Lider, Alas Purwo, Pantai Cemara, dan Baluran yang sedang gencar dibicarakan di sosial media, seperti Instagram.Di Desa Pakel, Dusun Durenan Timur, Kecamatan Licin, Kabupaten Banyuwangi, terdapat wisata air terjun yang diberi nama Kedung Angin, yang dalam bahasa Osing berarti 'sebuah kubangan yang berangin'. Karena deras air terjun dan kontur bebatuan menimbulkan suara seperti angin.

Air terjun yang memiliki tinggi sekitar lima meter ini berasal dari hulu Pegunungan Ijen. Jadi tidak heran jika airnya dingin dan segar. Selain itu, pengunjung dapat berenang sesuka hati menikmati sensasi kesegaran dari air terjun Kedung Angin. Kedalaman kedung mencapai dua meter dan lebar 800 meter. Di area Kedung Angin, pengunjung tidak hanya disuguhi pemandangan yang asri dan air yang segar. Untuk pengunjung yang hobi naik motor trail juga dapat menikmati jalur menuju ke dalam hutan yang lebih dalam. Di sana pengunjung akan banyak menemui monyet hutan dan berbagai binatang liar lainnya.

Permasalahan yang muncul dari daya tarik air terjun Kedung Angin adalah dari tata kelola destinasi, meskipun sudah terdepat beberapa fasilitas seperti sign penunjuk arah, gapura tempat masuk ke kawasan daya tarik, tempat parkir, gazebo, dan juga toilet. Akan tetapi seiring berjalannya waktu ditambah pandemi Covid 19 fasilitas-fasilitas tersebut mulai rusak. Tidak hanya itu dikarenakan daerahnya yang terpencil di tengah hutan pinus membuat tempat ini jarang terekspose ke media sosial dan khalayak umum, sehingga sering dijadikan tempat bolos siswa-siswi sekolah. Ditambah lagi beberapa pemuda sekitar juga memanfaatkan lingkungan air terjun Kedung Angin untuk pesta minum-minuman keras dan berujung pada sampah plastik yang berantakan.

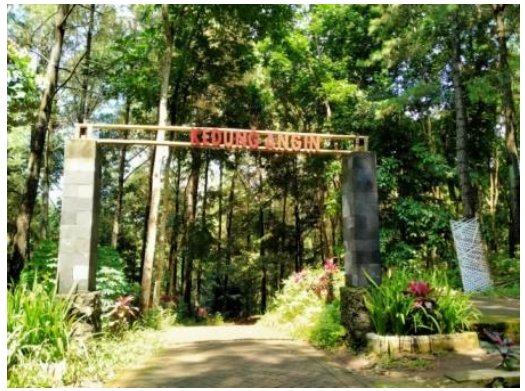

(a)

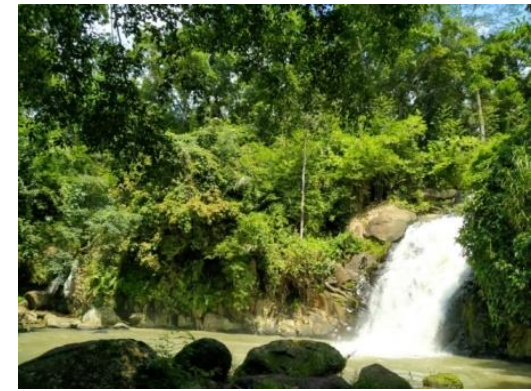

(b)

Gambar 1. (a) Pintu Masuk Kedung Angin (b) Tampilan Air Terjun Kedung Angin

Dilansir dari laman https://kabarbanyuwangi.info air terjun Kedung Angin dengan beberapa mitos dan kisah yang meliputinya, Kedung Angin adalah daya tarik wisata yang menarik untuk dikunjungi, susananya yang tenang dapat menjadi lokasi relaksasi dan sejenak keluar dari kebisingan kehidupan kota. Lokasinya yang cukup jauh dari pemukiman warga, berlibur di air terjun ini tidak akan terganggu aktifitas penduduk. Sesekali burung-burung khas pepohonan pinus dan durian hinggap dan berpindah ke bebatuan di sekitar air terjun. Kondisi sekitar seperti kedung masih tamak bersih dan asri. Belum terlalu banyak sampah berserakan seperti yang biasa ditemui di beberapa tempatwisata di Banyuwangi (Sidekick, 2016).

Problematika yang mendasar dari daya tarik wisata air terjun Kedung Angin adalah minimnya pengetahuan tentang dunia pariwisata dan rendahnya SDM warga sehingga manajemen tata kelola destinasi pariwisata di lingkungan air terjun Kedung Angin belum maksimal ditambah dengan adanya pandemi Covid 19 yang sempat membuat wisata di 
Banyuwangi dan air terjun ini tutup total, sehingga setelah era kebiasaan baru digulirkan, perlu adanya Bimbingan Teknis (BIMTEK) kepada pengelola yang dalam hal ini adalah Badan Usaha Milik Desa (BUMDes) Pakel, karang taruna, dan masyarakat sekitar yang berjualan makanan dan minuman di sekitar air terjun untuk melakukan suatu strategi dan langkah nyata menyambut kebiasaan baru di bidang pariwisata mulai dari tata kelola hingga strategi pemasaran yang dalam kegiatan ini berfokus ada Digitalisasi Promosi Pariwisata berbasis website dan media sosial sehingga wisata air terjun Kedung Angin dapat menjadi daya tarik iwisata berkelanjutan yang dapat mengangkat ekonomi masyarakat sekitar.

Berdasarkan pemaparan tersebut dan kondisi era kebiasaan baru (new normal) untuk industri pariwisata maka tim pelaksana Pengabdian Kepada Masyarakat (PKM) Program Studi D-IV Manajemen Bisnis Pariwisata akan melakukan Bimbingan Teknis (Bimtek) tentang manajemen tata kelola dan Digitalisasi Promosi Pariwisata berbasis website dan media sosial mengingat pandemi Covid 19 menjadi cobaan yang dihadapi oleh seluruh lapisan masyarakat sehingga berdampak pada sektor pariwisata dan juga ekomoni, dengan dimulainya kebiasaan baru dan mulai dibukanya beberapa destinasi wisata di Banyuwangi, Bimbingan Teknis yang akan diberikan harapannya dapat memberikan suntikan moral dan semangat warga di area sekitar air terjun Kedung Angin, BUMDes dan masyarakat Desa Pakel pada umumnya dapat sustain dengan tetap mengedepankan kearifanlokal dan menjaga ekosistem lingkungan sekitar.

Pelatihan/Bimbingan Teknis (Bimtek) adalah suatu kegiatan dimana para peserta diberi pelatihan-pelatihan yang bermanfaat dalam meningkatkan kompetensi peserta yang dimana materi yang diberikan meliputi Membangun Tim Kerja Efektif, Teknik Komunikasi dalam Konteks Pelayanan Prima, Survey Indeks Kepuasan Masyarakat dan Penanganan Keluhan Pelanggan, Tata Pemerintahan yang Baik dan Profesionalisme Aparatur, Kepemimpinan, dan lainnya (Aminin, 2015). Salah satu destinasi pariwisata yang memiliki tujuan sebagai kawasan wisata alam adalah air terjun Kedung Angin di Dusun Durenan Desa Pakel. Pengelola (BUMDes) air terjun Kedung Angin memiliki keinginan untuk menjadikan pariwisata sebagai salah satu sektor unggulan. Dalam tiga tahun terakhir pada perspektif internasional menunjukan bahwa pola pengelolaan kolaboratif dalam konteks pariwisata semakin mengemuka. Pola ini disebut pula Destination Management Organization (DMO) (Trihayuningtyas, Rahtomo, \& Darmawan, 2018).

Permasalahan yang terjadi adalah banyaknya sumberdaya alam yang dapat dimanfaatkan dalam bidang pariwisata, sumberdaya manusia yang jumlahnya dapat dimanfaatkan sebagai tenaga kerja bidang pariwisata dan sumberdaya potensial lain yang belum dimanfaatkan secara optimal, maka dibutuhkan Bimbingan Teknis (Bimtek) kepada pengelola yang dalam hal ini adalah Badan Usaha Milik Desa (BUMDes) Pakel, karang taruna, dan masyarakat sekitar yang berjualan makanan dan minuman di sekitar air terjun untuk melakukan suatu strategi dan langkah nyata menyambut kebiasaan baru di bidang pariwisata mulai dari tata kelola hingga strategi pemasaran yang dalam kegiatan ini berfokus ada Digitalisasi Promosi Pariwisata berbasis website dan media sosial. Disamping itu yang tidak kalah penting adalah tetap melakukan kolaborasi dan sinergi yang baik dengan berbagai pihak dalam melakukan digitaliasasi promosi sehingga dapat melestarikan lingkungan, mengedepankan kearifan lokal, dan menggerakkan UMKM di Desa Pakel dan lingkungan sekitar Air Terjun Kedung Angin.

\section{METODE}

Metode yang digunakan dalam kegiatan ini adalah bimbingan teknis teknis berupa pelatihan dan pendampingan untuk meningkatkan kompetensi peserta khususnya dibidang promosi pariwisata di air terjun Kedung Angin di Dusun Durenan Desa Pakel dan juga mengacu pada aspek manajemen tata kelola dengan konsep Destination Management Organization (DMO) mengacu pada apa yang telah dilakukan (Darmawan, Kanom, \& Nurhalimah, 2020) dan (Kristiana, 2016). Peran DMO menurut Destination Consultancy Group di dalam Morisson (2013), memiliki 6 peran kepemimpinan dalam pariwisata dalam tujuan keseluruhan untuk pariwisata di masa depan. Pada program PKM ini BIMTEK berfokus pada Pengembangan Produk 
dan Pemasaran \& Promosi (Digitalisasi Promosi) berbasis website dan media sosial dengan pendekatan Pariwisata Berbasis Masyarakat (Community Based Tourism/ CBT) dan Ekowisata. Gambar 2 berikut ini adalah skema langkah-langkah kegiatan PKM yang dilakukan.

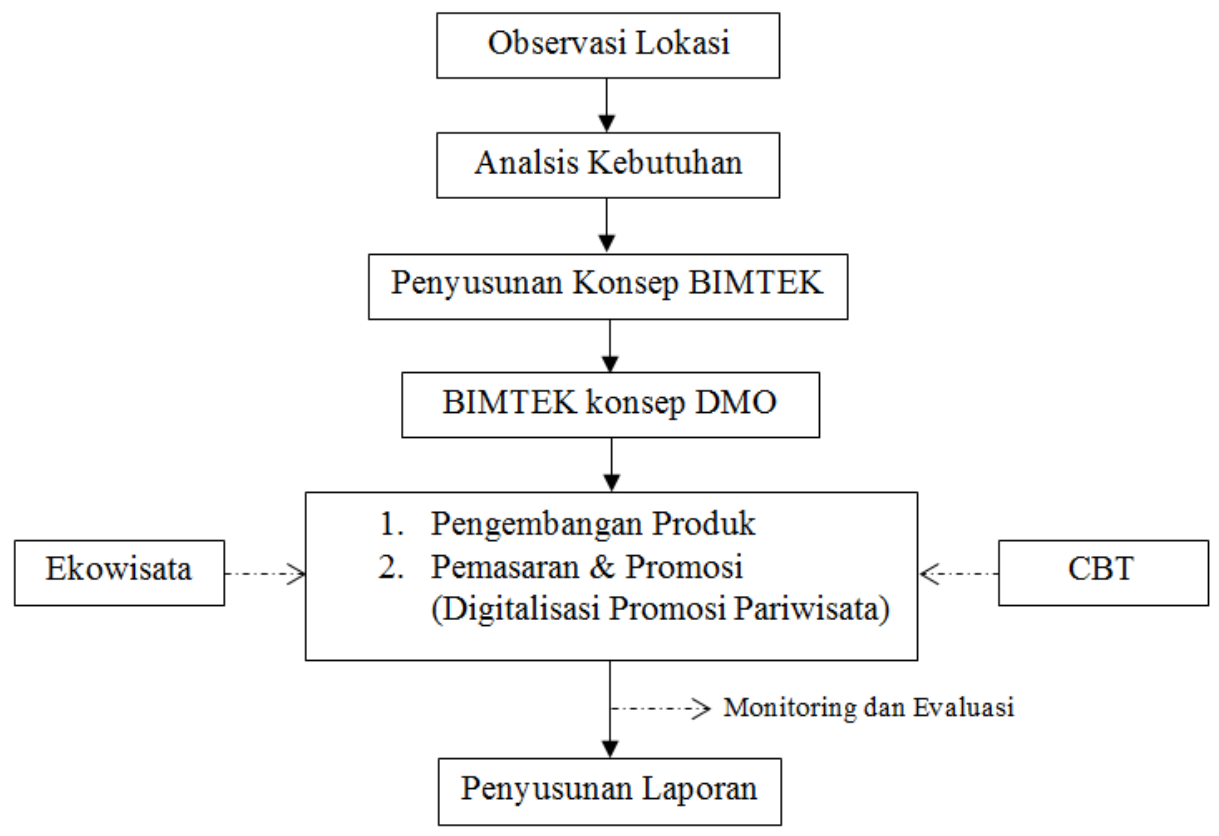

Gambar 2. Skema Langkah-langkah Pengabdian

Berdasarkan Gambar 2 tersebut diawali dengan observasi awal lokasi Air Terjun Kedung Angin beserta melakukan kerja sama dengan mitra, sehingga dapat dianalisis awal permasalahan dan kebutuhan awal dari kegiatan PKM ini, langkang berikutnya adalah penyususnan konsep Bimtek yang sesuai dengan target mitra, mengingat lokasi Desa Pakel yang terpencil dan mayoritas masih gagap teknologi (gaptek) sehingga dalam pelaksanaannya perlu pelatihan pendampingan. Kunci serangkaian kegiatan ini adalah dikembangkan produk Digitalisasi Promosi Pariwisata berbasis website dan media sosial dengan pendekatan CBT dan Ekowisata, yang intinya akan dibuatkan website, youtube, facebook, dan instagram serta pendampingan dalam bentuk Bimtek untuk melakukan manajerial terhadap produk yang sudah dibuat dengan tujuan BUMDes Pakel lebih dapat berkreasi dan meningkatkan kreatifitas masyarakat muda sekitar seiring dengan perkembangan teknlogi informasi seperti saat ini.

\section{HASIL DAN PEMBAHASAN}

Digitalisasi telah merambah ke semua sektor kehidupan manusia, termasuk dunia pariwisata. Untuk mengenalkan dan mengembangkan sektor pariwisata, mustahil suatu negara melakukannya secara konvensional. Destinasi digital ialah gerakan mengampayekan daya tarik wisata lewat media sosial secara masif berupa berbagai kegiatan yang sudah terdokumentasikan, baik video maupun foto, yang disebarluaskan ke publik. Tujuan dari destinasi digital tak lain dan tak bukan adalah promosi.

\subsection{Pembuatan Video Promosi}

Video promosi yang dibuat mengedepankan konsep ekowisata, mengingat lokasi Air Terjun Kedung Angin berada ditengah hutan dan akses ke lokasi melalui jalan dataran tinggi dengan pemandangan alam yang sejuk dan asri. Berikut beberapa screenshot video promosi yang dibuat dengan durasi kurang lebih 2 menit. 


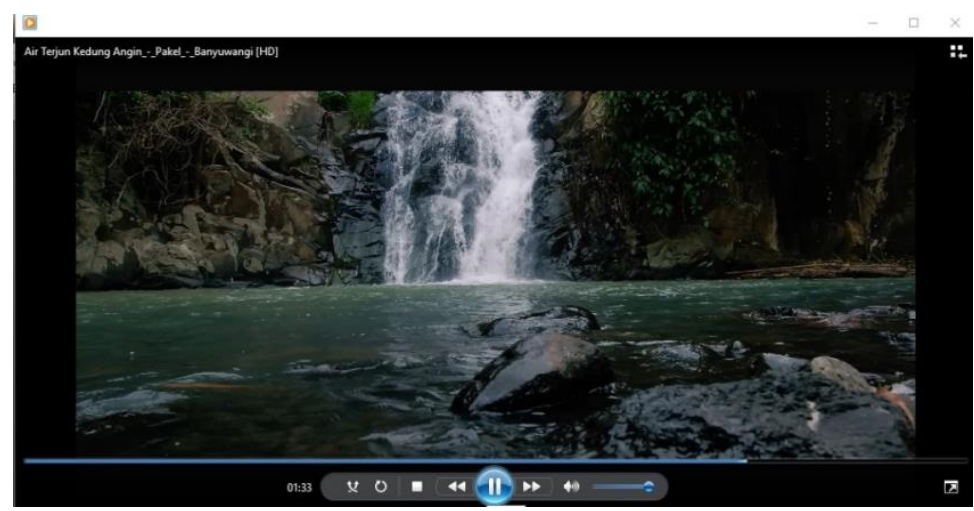

Gambar 3. Scene Spot Air Terjun Kedung Angin Banyuwangi

Gambar 3 tersebut merupukan tangkapan video promosi Air Terjun Kedung Angin yang terlihat jernihdan bersih dipadukan dengan panorama alam yang sejuk, hijau, dan asri. Video tersebut sudah terunggah sehingga dapat dilihat dan diunduh pada link berikut https://www.youtube.com/watch?v=RYb7AnifSMI\&t=6s. Video promosi sudah ditayangkan dan ditonton lebih dari 100 kali di kanal youtube, dibagikan dan diputar berkali-kali di media facebook dan instagram, hal ini menjadi salah satu strategi nyata di era digital untuk mempromosikan suatu daya tarik wisata yang punya potensi untuk dikembangkan.

\subsection{Pembuatan Website}

Fungsi website adalah sebagai sarana untuk menyampaikan informasi terbaru dan menarik untuk dibaca oleh customer atau pelanggan anda. Pada dasarnya, website juga dapat dijadikan sebagai sarana edukasi, pembelajaran, tutorial, tips \& trik, dan masih banyak lagi. Contoh website sebagai sarana informasi adalah situs pencarian berita, website company profile, dan lainnya. Untuk jenis kontennya, dapat berupa video, teks, dan gambar.

Website yang dibuat dalam kegiatan PKM ini berbasis WordPress yang isinya berupa informasi arah menuju Air TerjunKedung Angin, Gallery Air Terjun Kedung Angin, dan video promosi yang sudah dibuat yang terkoneksi ke kanal youtube. Harapannya adalah dengan adanya website ini yang nantinya akan dikelola oleh BUMDes dengan pendampingan tim PKM dapat meningkatkan konsep Pariwisata Digital sehingga Air Terjun Kedung Angin lebih dikenal oleh masyarakat Banyuwangi maupun luar Banyuwangi. Gambar 4. berikut adalah tampilan website https://kedungangin.com/.

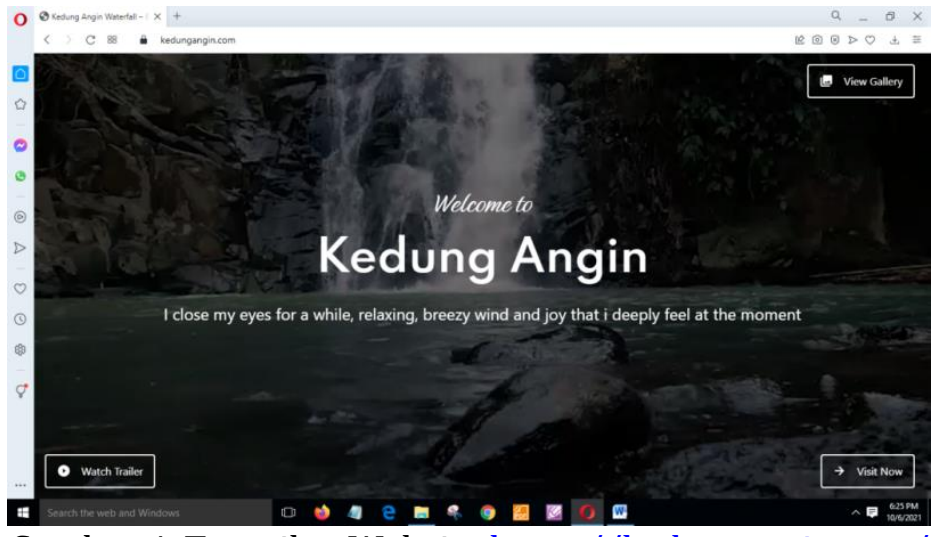

Gambar 4. Tampilan Website https://kedungangin.com/

Berdasarkan Gambar 4 tersebut wesbite yang dibuat oleh tim PKM selanjutkan akan dikelola dan dikebangkan lagi oleh BUMDes dengan terus dilakukan monitoring dan evaluasi, dalam Gambar 4 tersebut terdapat 3 menu yaitu Watch Trailer berisi video promosi dari youtube, Visit Now berisi informasi dari google map sebagai penunjuk arah menuju lokasi air terjun, dan View Gallery berisi informasi spot-spot foto di sekitar Air Terjun Kedung Angin. 
Harapan tim PKM dengan adanya website tersebut dapat memberikan informasi kepada pengujung jika ingin melakukan kegiatan wisata alam ke Banyuwangi dengan melakukan pencarian random di mesin pencari google sehingga muncul website Kedung Angin.

\subsection{Pelaksanaan Bimbingan Teknis Digitalisasi Promosi}

Mengingat masih masa pandemi Covid-19 maka Bimtek dilaksanakan dengan jumlah peserta yang terbatas yaitu 12 peserta dengan penyampaian materi tentang pengetahuan dasar konsep ekowisata, pariwisata berbasis masyarakat, dan pengelolaan website serta pemanfaatan media sosial sebagai senjata utama melakukan digitalisasi promosi terutama dengan pendekataan pariwisata digital, mengingat Air Terjun Kedung Angin masih belum dimanfaatkan dan dikelola secara baik, mengingat tren pariwisata tahun 2021 pasca pandemi, wisatawan lebih condong ke daya tarik berbasis alam atau lebih sering disebut Nature Eco Wellness Adventure (NEWA) yang mana Air Terjun Kedung Angin memenuhi kriteria sebagai daya tarik wisata NEWA tersebut.

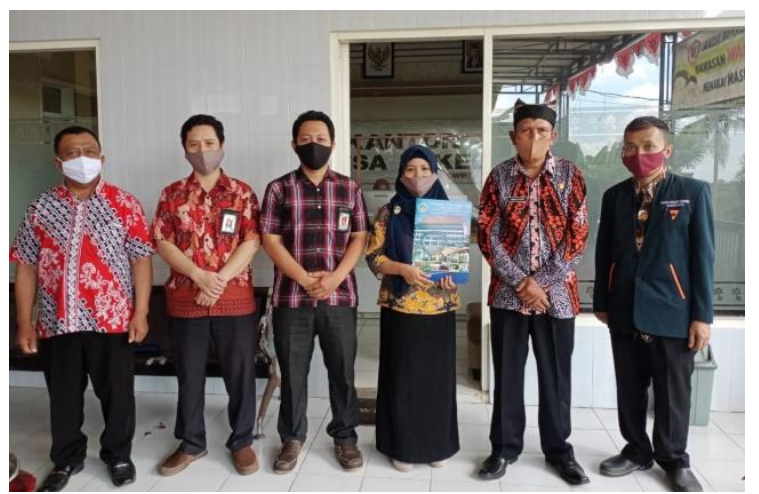

Gambar 5. Bimbingan Teknis Digitalisasi Promosi Dengan Pemerintah Desa Pakel

Berdasarkan Gambar 5 tersebut tim PKM melakukan Bimtek dengan Pemerintah Desa Pakel dan juga Ketua BUMDes tentang tata kelola daya tarik wisata, dalam hal ini perbaikan sarana dan prasarana yang ada di Air Terjun Kedung Angin seperti pembersihan akses jalan menuju lokasi, perbaikan papan informasi "Kedung Angin", perbaikan tempat parkir, gazebo, dan perbaikan toilet. Hal ini dikarenakan untuk terwujudnya suatu daya tarik wisata yang baik minimal terdapat 3A yakni atraksi, aksesibilitas, dan amenitas yang ketiganya harus dikelola dengan baik, baru setelah itu dilakukan digitalisasi promosi daya tarik wisata.

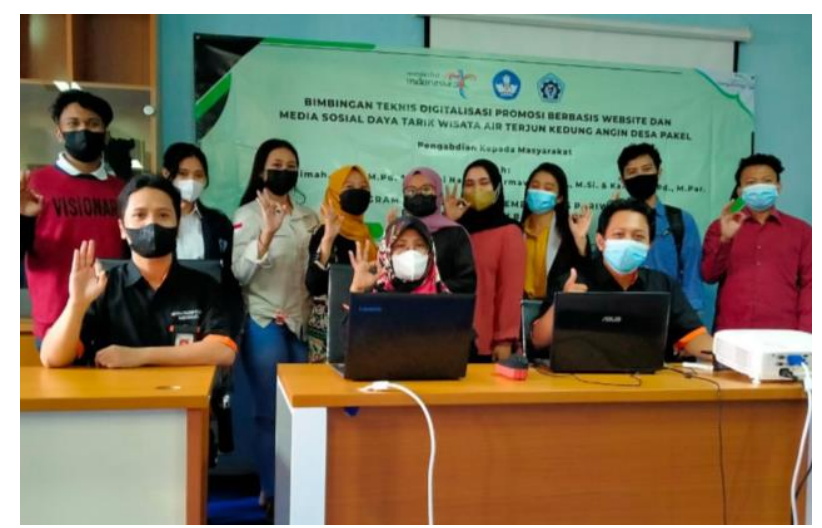

Gambar 6. Bimbingan Teknis Digitalisasi Promosi Dengan Pemuda Desa Pakel

Langkah berikutnya adalah Bimtek dengan metode pelatihan dan pendampingan, berdasarkan Gambar 6 tersebut tim PKM menargetkan digitalisasi promosi kepada pemuda Desa Pakel yang tergabung dalam BUMDes dan sebagian Karang Taruna guna memaksimalkan pemanfaatan website dan media sosial. Dalam kegiatan tersebut pemuda desa dibekali 
pengelolaan dasar website berbasis wordpress untuk update informasi seputar Air Terjun Kedung Angin, dan juga melakukan postingan video promosi yang telah dibuat di akun media sosial masing-masing dengan menambkan tagline "Restrat Tourism, Take Action" dan juga dengan menggunakan hastag "\#majesticbanyuwangi, \#wonderfulindonesia, \#poliwangi_jinggo, \#kemendikbudristek, dan \#kemenparekraf" sebagai upaya untuk memperkenalkan Air Terjun Kedung Angin yang dianggap biasa menjadi luar biasa.

\subsection{Keberlanjutan Program Digitalisasi Promosi}

Harapan Tim PKM kepada pengelola daya tarik wisata Air Terjun Kedung Angin yang dalam hal ini adalah BUMDes Pakel dapat melakukan suatu promosi sepanjang masa mengingat "Tren Pariwisata 2021" (next normal tourism) Banyuwangi menjadi destinasi prioritas dengan Triangle Diamond yang semuanya adalah NEWA, lokasi Air Terjun Kedung Angin di Desa Pakel merupakan rute alternatif menuju Desa Licin, Desa Taman Sari, dan Taman Wisata Alam Kawah Ijen yang menjadi Ijen Geopark. Oleh karena sebagai daya tarik yang menjadi supporting system kawasan Ijen Geopark perlu adanya keterlibatan masyarakat dalam perencanaan, manajemen tata kelola, hingga digitaliasasi promosi yang nantinya dapat melestarikan lingkungan, mengedepankan kearifan lokal, dan menggerakkan UMKM di Desa Pakel dan lingkungan sekitar Air Terjun Kedung Angin.

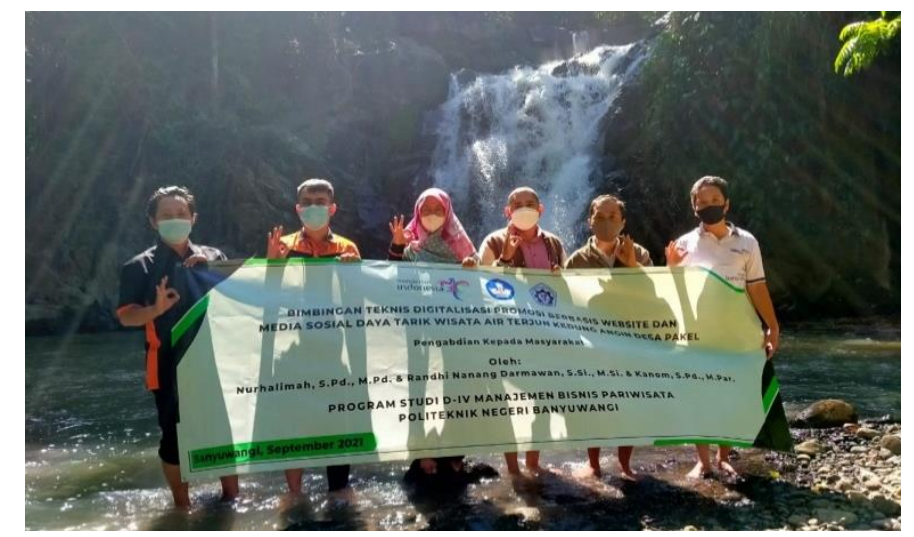

Gambar 7. Tim PKM di Air Terjun Kedung Angin Bersama Akademisi Pariwisata

Tim PKM terus melakukan pendampingan (monitoring \& evaluasi) agar Air Terjun Kedung Angin tetap bisa dinikmati oleh pengunjung tidak hanya dalam waktu sesaat melainkan dalam jangka waktu yang lama, sehingga berdasarkan Gambar 7, Tim PKM menggandeng Akademisi Pariwisata juga melakukan promosi dan juga sharing diskusi untuk keberlanjutan daya tarik ini, sehingga Air Terjun Kedung Angin memberikan multiplier effect kepada masyarakat Dusun Durenan Desa Pakel Kecamatan Licin Kabupaten Banyuwangi.

\section{KESIMPULAN}

Manajemen tata kelola dengan konsep DMO masih belum begitu maksimal meskipun beberapa sarana pendukung seperti papan informasi "Kedung Angin", tempat parkir motor, toilet, dan beberapa semak belukar sudah diperbaiki dan terlihat lebih bersih, namun terlepas dari itu pelu peran aktif dari pengelola yaitu BUMDes Pakel beserta dengan masyarakat sekitar untuk aktif terlibat dalam perencanaan serta pengembangan daya tarik wisata Air Terjun Kedung Angin.

Digitalisasi promosi daya tarik wisata Air Terjun Kedung Angin sudah dilakukan dengan maksimal melalui pembuatan video promosi berdurasi 2 menit dan pembuatan website https://kedungangin.com yang semuanya dikolaborasikan melalui media sosial facebook dan instagram serta story whatsapp, dengan harapan produk yang sudah dikembangkan dan pemberian bimbingan teknis dari Tim PKM dapat bermanfaat bagi pengelola (BUMDes) dan 
masyarakat sekitar sehingga saat Air Terjun Kedung Angin menjadi Pariwisata Digital maka dapat menggerakkan UMKM di Desa Pakel dan lingkungan sekitar Air Terjun Kedung Angin sendiri.

\section{UCAPAN TERIMA KASIH}

Penulis mengucapkan terima kasih kepada Pusat Penelitian dan Pengabdian kepada Masyarakat (PPPM) Politeknik Negeri Banyuwangi sehingga kegiatan pengabdian ini lolos pendanaan Pengabdian Kepada Masyarakat dengan sumber dana dari PNBP Politeknik Negeri Banyuwangi Tahun Anggaran 2021, serta beberapa pihak terkait sehingga pengabdian ini dapat terselesaikan dengan baik.

\section{DAFTAR PUSTAKA}

Aminin, S. (2015). Manual Prosedur Bimbingan Teknis (BIMTEK). Malang: Lembaga Penelitian dan Pengabdian Kepada Masyarakat Universitas Brawijaya.

Darmawan, R. N., Kanom, \& Nurhalimah. (2020). Bimbingan Teknis Manajemen Tata Kelola Destinasi Pariwisata di Wisata Pinus Songgon Banyuwang. Jurnal Abdidas, 1(6), 539-546.

Kristiana, Y. (2016). Monitoring Dan Evaluasi Pengembangan Destination Management Organization Kementerian Pariwisata. Jurnal Sinergitas PKM dan CSR, 1(1), 63-75.

Morisson, A. (2013). Destination management and destination marketing: The platform for excellence in tourism destinations. Tourism Review, 28(1), 6-9.

Sidekick. (2016). Kabar Banyuwangi. Retrieved April 2, 2021, from kabarbanyuwangi.info: https://www.kabarbanyuwangi.info/kedung-angin-air-terjun-menawan-di-tengahlebatnya-hutan-pinus.html

Trihayuningtyas, E., Rahtomo, W., \& Darmawan, H. (2018). Rencana Tata Kelola Destinasi Pariwisata Kawasan Pulau Camba-Cambang Dan Sekitarnya Di Kabupaten Pangkajene Dan Kepulauan. Jurnal Manajemen Resort dan Leisure, 15(1), 33-47.

Winarta, K. (2017). Liputan6. Retrieved April 2, 2021, from liputan6.com: https://www.liputan6.com/citizen6/read/3021429/kedung-angin-damainya-danau-dihutan-pedalaman-banyuwangi 